Cell Research(1994),4, 183-189

\title{
Plants regenerated from mesophyll protoplasts of white mulberry
}

\author{
WEI ZHIMING*1, ZHIHONG XU*,JIANQIU HUANG*. \\ NONG XU**, MINREN HUANG** \\ * National laboratory of Plant Molecular Genetics, Shang- \\ hai Institute of Plant Physiology, Academia Sinica, 300 \\ Fenglin Road, Shanghai 200032, China \\ ** Forest Tree Genetics and Breeding Laboratory, Nanjing \\ Forest University, Nanjing 210037, China
}

\section{ABSTRACT}

Morus alba(white mulberry) mesophyll protoplasts were isolated from leaves of 30-45 day old sterile shoots, with protoplast yields of $2.5 \times 10^{7} \mathrm{~g}^{-1} /$ F.W. after purification. The protoplasts were cultured in a modified K8P liquid medium containing $0.2 \mathrm{mg} / \mathrm{L} 2,4-\mathrm{D}(2,4$ - Dichlorophenoxy acetic acid), $1 \mathrm{mg} / \mathrm{L} \mathrm{NAA(Naphthyl} \mathrm{acetic} \mathrm{acid)} \mathrm{and}$ $0.5 \mathrm{mg} / \mathrm{L} \mathrm{BA}(6$-benzylaminopurine). A low plating density $\left(5 \times 10^{4} / \mathrm{ml}\right)$ proved to be favourable to the division of protoplast-derived cells. The first division occurred 4 days after culture, and the division frequency reached $24 \%$ at 10 days. A number of cell colonies and microcalli formed in 6 weeks. The microcalli were transferred onto MSB medium with $0.5 \mathrm{mg} / \mathrm{L} \mathrm{NAA}$ and $0.5 \mathrm{mg} / \mathrm{L} \mathrm{BA}$ for further proliferation. Shoot formation was initiated when the calli of 3-4 mm in size were transferred onto MSB differentiation medium with $0.1 \mathrm{mg} / \mathrm{L} \mathrm{NAA}$ and $1 \mathrm{mg} / \mathrm{L} \mathrm{BA}$. The frequency of shoot formation was $35 \%$. The shoots of 4$5 \mathrm{~cm}$ in height were excised from the callus and rooted on half strength MS medium with $0.5 \mathrm{mg} / \mathrm{L} \mathrm{IBA}$ and 0.1 $\mathrm{mg} / \mathrm{L}$ BA. After transplantation into pots, the regenerated plants grew vigorously in the phytotron.

Key words: Morus alba L., white mulberry, protoplast culture, plant regeneration.

1. Corresponding author. 
Plant regeneration from protoplasts of white mulberry

\section{INTRODUCTION}

Protoplast culture is one of the most rapidly developing areas in plant tissue culture, because of its importance in plant genetic manipulation. However, so far, there are only a few forest tree species in which plant regeneration from protoplasts has been successful, namely Liriodendron tulipifera[1], Paulownia fortunei[2], Picea glauca[3], Platanus orientalis[4], Populus sp.[5-8], Santalum album[9], Solanum dulcamara[10] and Ulmus [1]. White mulberry (Morus alba) is an important woody feed crop for the silkworm. Some tissue culture has been carried out with this species, in an attempt to provide artificial feed containing cultured mulberry cells and for clonal propagation (see Review of Oka and Ohyama, [12]). In this paper, we report plant regeneration from mesophyll protoplasts of this species.

\section{MATERIALS AND METHODS}

\section{Plant material}

White mulberry seeds, collected in our institute, were surface-sterilized by dipping in $70 \%$ alcohol for $30 \mathrm{sec}$ and then soaking in a sodium hypochlorite solution (containing $0.5 \%$ of effective chlorine) for $15 \mathrm{~min}$. After being washed with sterile water (4 changes), the sterilized seeds germinated on hormone-free MS medium[13]. Apical buds cut from the seedlings were cultured on MS medium supplemented with $0.2 \mathrm{mg} / \mathrm{L}$ BA (at $25{ }^{\circ} \mathrm{C} ; 2000 \mathrm{Lux}, 12 \mathrm{~h} /$ day) for inducing formation of multiple shoots. The multiple shoots formed were subcultured once a month for micropropagation of the plant material.

\section{Protoplast isolation and culture}

Young expanded leaves, collected from 30-45 day old cultured shoots, were cut into 0.5-1 mm strips and plasmolyzed for $1.5-2 \mathrm{~h}$ in $\mathrm{CPW}-11 \mathrm{M}$ (containing $11 \%$ mannitol). For releasing protoplasts, the leaf strips were digested statically in an enzyme solution for $4 \mathrm{~h}$ and then on a shaker (35 rpm) for $1 \mathrm{~h}$. The enzyme solution was consisted of 1\% Cellulase Onozuka R-10, Macerozyme $\mathrm{R}-10$ and $0.05 \%$ Pectoltase $\mathrm{Y}-23$ in $\mathrm{CPW}-9 \mathrm{M}$ (containing 9\% mannitol), $\mathrm{pH}$ 5.7. The protoplasts in enzyme solution were filtered through an $45 \mu \mathrm{m}$ nylon sieve and collected by centrifuging at 800 $\mathrm{rpm}$ for $4 \mathrm{~min}$. They were purified by using a routine procedure employing floatation in CPW $-18 \mathrm{~S}$ (containing 18\% sucrose) and 3 washes in CPW -9M solution (centrifuged at $1000 \mathrm{rpm}$ for $3 \mathrm{~min}$ ). The purified mesophyll protoplasts were counted and protoplast viability was examined with $0.1 \%$ FDA in $0.35 \mathrm{~mol} / \mathrm{L}$ glucose solution.

The mesophyll protoplasts were cultured in $6 \mathrm{~cm}$ plastic dishes, each containing $2 \mathrm{ml} \mathrm{K8P}$ liquid medium[14], supplemented with $0.2 \mathrm{mg} / \mathrm{L} 2,4-\mathrm{D}, 1 \mathrm{mg} / \mathrm{L}$ NAA and $0.5 \mathrm{mg} / \mathrm{L} \mathrm{BA}$, at densities of $1 \times 10^{4}, 5 \times 10^{4}, 1 \times 10^{5}, 5 \times 10^{5}, 1 \times 10^{6}$ and $5 \times 10^{6}$ protoplasts / $\mathrm{ml}$ to compare the effect of plating density on the division of the protoplast- derived cells. The dishes were placed at $25 \pm 1^{\circ} \mathrm{C}$ in dark. Division frequency was counted at 10 day. After small colonies formed (about $10 \mathrm{~d}$ ), the dishes were moved under light (about $500 \mathrm{lux}$ ), and the cultures were diluted at $10 \mathrm{~d}$ intervals with $0.5 \mathrm{ml}$ K8 medium[14] with $0.1 \mathrm{mg} / \mathrm{L}$ 2,4-D, $1 \mathrm{mg} / \mathrm{L}$ NAA and $0.2 \mathrm{mg} / \mathrm{L}$ BA, for sustaining cell divisions and further stimulating cell colony formation and growth. Plating efficiency (\% of number of small calli and cell colonies formed in the total number of the protoplasts cultured) was counted after 5-6 weeks of culture when small calli of $0.5-1.0 \mathrm{~mm}$ in size formed.

\section{Callus proliferation}

The small calli of 0.5-1.0 mm in size were transferred onto MSB growth medium (containing MS 
minerals[13] and $B_{5}$ organic components[15]) supplemented with 0.1-0.5 mg/L NAA and 0.25-1.0 $\mathrm{mg} / \mathrm{L} \mathrm{BA}$ for further growth and proliferation. The culture conditions were $25 \pm 1^{\circ} \mathrm{C}$ with a $12 \mathrm{~h}$ photoperiod at 1000 Lux.

\section{Plant regeneration}

After 2 weeks on MSB growth medium, the calli grew up to 3-4 mm in size. Compact and light yellow calli were picked out and transferred onto MSB differentiation media with different types and concentrations of hormones for shoot formation. Shoots of 4-5 cm in height were cut off and rooted on half strength MS medium with $0.5 \mathrm{mg} / \mathrm{L} \mathrm{IBA}$ and $0.1 \mathrm{mg} / \mathrm{L} \mathrm{BA}$. Regenerated plants were transplanted into pots, and grown in the phytotron of our institute.

\section{RESULTS and DISCUSSION}

Mulberry protoplasts were readily isolated from young expanded leaves of sterile shoots (Fig 1, 2), with a high yield of $2.5 \times 10^{7} \mathrm{~g} / \mathrm{F}$.W. after purification. FDA fluorescent staining showed that the viability of isolated protoplasts reached $96.8 \%$. Pretreatment of the leaf strips in CPW-11M for plasmolysis reduced the time required for enzymatic digestion. Incubation in enzyme solution, firstly in stationary and then on a shaker, caused less damage to protoplasts and was beneficial to maintain protoplast survival.

The data listed in Tab 1 showed that protoplast density in culture apparently affected the divisions of the protoplast-derived cells. Within range of $1 \times 10^{4}-5 \times 10^{6}$ $/ \mathrm{ml}$, the best results of time needed to initiate the first division and division frequency was from the group of $5 \times 10^{4} / \mathrm{ml}$ protoplast density. In this case, the first division was observed at $4 \mathrm{~d}$ (Fig 3), the second division at $7 \mathrm{~d}$ (Fig 4), with cell clusters at $12 \mathrm{~d}$ (Fig 5). Higher densities $\left(5 \times 10^{5}, 1 \times 10^{6}, 5 \times 10^{6}\right)$ were unsuitable for the initiation of division and its maintenance for colony formation. It was demonstrated that mulberry mesophyll protoplasts could be induced to divide and form colonies when they were cultured in a thin layer of liquid medium at lower density. A number of small calli of $0.5-1.0 \mathrm{~mm}$ in size formed after 6 weeks of culture (Fig 6).

Tab 1. Effect of protoplast densities on division frequency

\begin{tabular}{ccccc}
\hline $\begin{array}{c}\text { Protoplast } \\
\text { density } \\
\text { (per ml) }\end{array}$ & $\begin{array}{c}\text { 1st } \\
\text { division } \\
\text { (days) }\end{array}$ & $\begin{array}{c}\text { 2nd } \\
\text { division } \\
\text { (days) }\end{array}$ & $\begin{array}{c}\text { Colony } \\
\text { formation } \\
\text { (days) }\end{array}$ & $\begin{array}{c}\text { Division } \\
\text { frequency at } \\
10 \text { days }(\%)\end{array}$ \\
\hline & & & & \\
$1 \times 10^{4}$ & 6 & 8 & 14 & 18.8 \\
$5 \times 10^{4}$ & 4 & 8 & 12 & 24.0 \\
$1 \times 10^{5}$ & 7 & 9 & 16 & 16.4 \\
$5 \times 10^{5}$ & 7 & 9 & 18 & 15.4 \\
$1 \times 10^{6}$ & 10 & 12 & 19 & 7.2 \\
$5 \times 10^{6}$ & 10 & 14 & 21 & 6.5 \\
\hline
\end{tabular}


Plant regeneration from protoplasts of white mulberry

Hormone components in both the proliferation medium and the differentiation medium remarkably affected shoot regeneration from protoplast-derived calli (Tab 2 and 3). When the small calli of 0.5-1.0 mm were transferred onto MSB proliferation medium with $0.25-0.5 \mathrm{mg} / \mathrm{L}$ NAA and $0.25-1 \mathrm{mg} / \mathrm{L} \mathrm{BA}$, compact and light-yellow calli with a potential for shoot formation were formed (Fig 7)., From the data in Tab 2, the best results in shoot regeneration was obtained in the calli cultured on the proliferation medium with $0.5 \mathrm{mg} / \mathrm{L} \mathrm{NAA}$ and $0.5 \mathrm{mg} / \mathrm{L} \mathrm{BA}$. In order to test the effect of hormone component and concentration in differentiation medium on shoot formation, the calli of 3-4 mm in size cultured on the proliferation medium with $0.5 \mathrm{mg} / \mathrm{L} \mathrm{NAA}$ and $0.5 \mathrm{mg} / \mathrm{L} \mathrm{BA}$ were transferred onto MSB media supplemented with $0.1 \mathrm{mg} / \mathrm{L} \mathrm{NAA}$ and different concentrations of BA or ZT (zeatin). The data in Tab 3 show that the differentiation medium with $0.1 \mathrm{mg} / \mathrm{L} \mathrm{NAA}$ and $1 \mathrm{mg} / \mathrm{L}$

Tab 2. Effects of hormone components in proliferation medium on shoot regeneration from mesophyll protoplast-derived calli of muiberry

\begin{tabular}{|c|c|c|c|c|}
\hline $\begin{array}{l}\text { Proliferation } \\
\text { medium* } \\
(\mathrm{mg} / \mathrm{L})\end{array}$ & $\begin{array}{l}\text { Differenti- } \\
\text { ation medium* } \\
(\mathrm{mg} / \mathrm{L})\end{array}$ & $\begin{array}{c}\text { No. of } \\
\text { inoculated } \\
\text { calli }\end{array}$ & $\begin{array}{l}\text { No. of calli } \\
\text { with producing } \\
\text { shoots }\end{array}$ & $\begin{array}{c}\text { Frequency of } \\
\text { shoot forma- } \\
\text { tion }(\%)\end{array}$ \\
\hline NAA $0.1+\mathrm{BA} 1.0$ & & 100 & 0 & 0 \\
\hline NAA $0.25+\mathrm{BA} 0.25$ & & 120 & 3 & 2.5 \\
\hline NAA $0.25+\mathrm{BA} 0.5$ & & 125 & 5 & 4.0 \\
\hline NAA $0.25+\mathrm{BA} 1.0$ & NAA $0.1+\mathrm{BA} 1.0$ & 120 & 7 & 5.8 \\
\hline NAA $0.5+\mathrm{BA} 0.25$ & & 120 & 16 & 13.3 \\
\hline NAA $0.5+$ BA 0.5 & & 128 & 45 & 35.1 \\
\hline NAA $0.5+\mathrm{BA} 1.0$ & & 120 & 24 & 20.0 \\
\hline
\end{tabular}

* Basic medium: MSB-MS minerals $+\mathrm{B}_{5}$ organic components.

Tab 3. Effects of hormone components in differentiation medium on shoot regeneration from mesophyll protoplast-derived calli of mulberry

\begin{tabular}{clccc}
\hline $\begin{array}{c}\text { Proliferation } \\
\text { medium* } \\
(\mathrm{mg} / \mathrm{L})\end{array}$ & $\begin{array}{c}\text { Differentiation } \\
\text { medium* } \\
(\mathrm{mg} / \mathrm{L})\end{array}$ & $\begin{array}{c}\text { No. of } \\
\text { inoculated } \\
\text { calli }\end{array}$ & $\begin{array}{c}\text { No. of calli } \\
\text { with producing } \\
\text { shoots }\end{array}$ & $\begin{array}{c}\text { Frequency of } \\
\text { shoot forma- } \\
\text { tion }(\%)\end{array}$ \\
\hline & NAA 0.1+BA 0.5 & 86 & 18 & \\
NAA 0.5+BA 0.5 & NAA 0.1+BA 1.0 & 128 & 45 & 20.9 \\
& NAA 0.1+BA 2.0 & 114 & 29 & 35.1 \\
& NAA 0.1+ZT 1.0 & 90 & 14 & 25.4 \\
& NAA 0.1+BA 0.5+ & 102 & 24 & 15.6 \\
& ZT 0.5 & & & 23.5 \\
\hline
\end{tabular}

* Basic medium: MSB-MS mineral+ $\mathrm{B}_{5}$ organic components. 
Wei ZM et al.

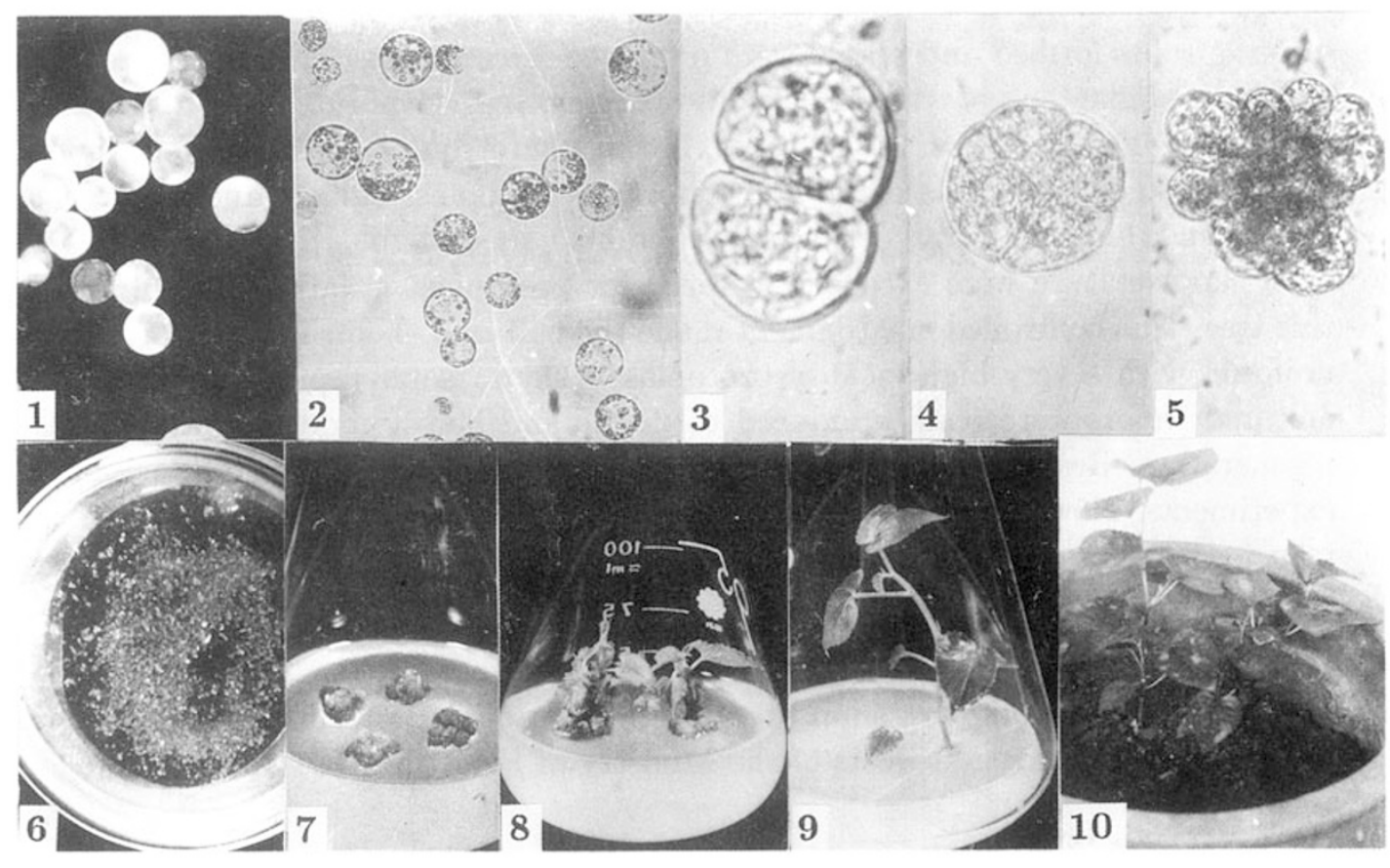

\section{Figure Explanation}

Fig 1-10. Protoplast culture and plant regeneration of white mulberry.

Fig 1. Viability of freshly isolated mesophyll protoplasts of white mulberry was examined with FDA (fluorescein diacetate) staining. Viable protoplasts made up $96.8 \%$ of the population. $\times 400$

Fig 2. Freshly isolated mesophyll protoplasts from sterile shoots. $\times 400$

Fig 3. The first division occurred after $4 \mathrm{~d}$ of culture. $\times 400$

Fig 4. The second division occurred after $7 \mathrm{~d}$ of culture. $\times 400$

Fig 5. Cell colony formed at $12 \mathrm{~d}$ in protoplast culture, $\times 100$

Fig 6. Protoplast-derived calli in $60 \times 15 \mathrm{~mm}$ plastic Petri dish, after 6 weeks of culture in K8p liquid medium with $0.2 \mathrm{mg} / \mathrm{L} \mathrm{2,4-D,} 1 \mathrm{mg} / \mathrm{L}$ NAA and 0.5 $\mathrm{mg} / \mathrm{L} \mathrm{BA}$.

Fig 7. Compact and light- yellow calli formed on MSB proliferation medium with 0.5 $\mathrm{mg} / \mathrm{L}$ NAA and $0.5 \mathrm{mg} / \mathrm{L} \mathrm{B} \mathrm{A}$.

Fig 8. Shoot formation on MSB differentiation medium with $0.1 \mathrm{mg} / \mathrm{L}$ NAA and 1 $\mathrm{mg} / \mathrm{L}$ BA.

Fig 9. Complete plant regenerated after rooting on half strength MS medium with $0.5 \mathrm{mg} / \mathrm{L}$ IBA and $0.1 \mathrm{mg} / \mathrm{L} \mathrm{BA}$.

Fig 10. The regenerated mulberry plant grown in pot. 
BA gave the best result. Green spots appeared on the calli 2-3 weeks after transfer onto this medium, followed by bud formation through organogenesis (Fig 8). The frequency of shoot formation reached $35 \%$. When green shoots of 4-5 $\mathrm{cm}$ in height were cut off and transferred onto half strength MS rooting medium, vigorously growing roots formed and plants were produced 2 weeks later (Fig 9). Some of the regenerated plants were transplanted into pots, with survival rate of more than $90 \%$. They grew into trees with 10-14 leaves, in the Phytotron of our institute (Fig 10).

To our knowledge, this is the first report on protoplast culture and plant regeneration in white mulberry. The results obtained showed that the expanded leaves from shoot culture were excellent material for protoplast isolation and culture for this tree. The controlled environment made the cultured shoots easily available and uniform, with a very high yield of protoplast. The mesophyll protoplasts from the cultured shoots were readily induced to divide and had a good potential of plant regeneration. Besides, the procedure we developed also gave high reproducibility in experiments. Now it is possible to improve this important tree species through gene transfer by using protoplasts as recipient.

\section{ACKNOWLEDGEMENTS}

This research work was supported by the National Biotechnology Programme and the Biotechnology Projects of the Ministry of Forestry (1991-1995).

\section{REFERENCES}

[1] Merkle SA, Sommer HE. Regeneration of Liriodendron tulipifera (Family Magnoliaceae) from protoplast culture. Amer J Bot 1987; 74:1317-21.

[2] Wei ZM, Kamada H, Harada H. Plant regeneration from leaf mesophyll protoplasts of Paulownia fortunei. Plant Tissue Culture Letters (Japan) 1991; 8:110-3.

[3] Attree SM, Dunstan DI, Fowke LC. Plantlet regeneration from embryogenic protoplasts of white spruce (Picea glauca). Bio / Technology 1989; 7:1060-2.

[4] Wei ZM, Xu ZH, Xu N, Huang MR. Mesophyll protoplast culture and plant regeneration of oriental planetree (Platanus orientalis). Acta Bot Sinica 1991; 33:813-8.

[5] Russell JA, McCown BH. Culture and regeneration of Populus leaf protoplasts isolated from non-seedlong tissue. Plant Science 1986; 46:133-42.

[6] Russell JA, McCown BH. Recovery of plants from leaf protoplasts of hybrid- popular and aspen clones. Plant Cell Reports 1988; 7: 59-62.

[7] Wang SP, Xu ZH, Wei ZM. Culture and regeneration of popular mesophyll protoplasts. Science in China(Ser.B) 1991; 34:587- 92.

[8] Park YG, Son SH. In vitro shoot regeneration from leaf mesophyll protoplasts of hybrid popular (Populus nigra X P. maximowiczii). Plant Cell Reports 1992; 11:2-6.

[9] Rad PS, Ozias-Akins P. Plant regeneration through somatic embryogenesis in protoplast cultures of sandalwood (Santalum album L.). Protoplasma 1985; 124:80-6.

[10]Chand PK, Davey MR, Power JB. Efficient plant regeneration from cell suspension protoplasts of the woody medicinal Solanum dulcamara L. (bitter-sweet, woody nightshade). Plant Cell Tissue \& Organ Culture 1990; 22:119-25.

[11] Sticklen MB, Domir SC, Limeberger RD. Shoot regeneration from protoplasts of Ulmus X 'Pioneer'. Plant Science 1986; 47:29-34. 
Wei ZM et al.

[12] Oka S, Ohyama K. Mulberry (Morus alba L.). In: Biotechnology in Agriculture and Forestry (Ed. Y.P.S.Bajaj), Springer-Verlag, 1986; 1:384-93.

[13] Murashige T, Skoog F. A revised medium for rapid growth and bioassays with tobacco tissue culture. Physiol Plant 1962; 15:473-97.

[14] Kao KN. Chromosomal behaviour in somatic hybrids of soybean-Nicotiana glauca. Mol Gen Genet 1977; 150:225-30.

[15] Gamborg OL, Miller RA, Ojima K. Nutrient requirements of suspension culture of soybean root cells. Exp Cell Res 1968; 50:151-8.

Received 20-6-1994. Revised 9-12-1994. Accepted 12-12-1994. 